\title{
The 'New Zealand Wars' or 'Land Wars'?: The Case of the War in Taranaki 1860-61
}

\author{
DANNY KEENAN \\ Massey University
}

When most New Zealanders reflect on the armed conflicts fought on New Zealand soil during the nineteenth century, the label 'the New Zealand Wars' generally springs to mind. Certainly, since the publication of James Belich's important book, The New Zealand Wars and the Victorian Interpretation of Racial Conflict, ${ }^{1}$ the label has become securely embedded into the psyche of most New Zealanders, especially those with a more than passing interest in New Zealand's nineteenth century history. Belich used the term throughout his book, as well as in his later popular television series of the same name. Running through the book, though less discernible in the television series, was the contention that these nineteenth century conflicts constituted a major war of sovereignty, one fought between defensive Maori tribes and an aggressive Crown. These wars were thus not mere storms in teacups; they were 'bitter and bloody struggles'. ${ }^{2}$ In the second episode of the television series, Belich stood on the site of Te Kohia Pa, just south of Waitara, a pa shelled by the British Army in March 1860, proclaiming it to be the place where 'the great civil wars of the 1860 s' began. ${ }^{3}$ These then were wars where a critical question was asked: who would rule New Zealand? The answer was the Crown, and the British Army ultimately prevailed over Maori and the King Movement in particular; and had done so by 1864. This was achieved despite (or so argues Belich) the skilful military innovations of Maori, especially the modern pa. ${ }^{4}$ New Zealand was therefore the reason for the war, and New Zealand was the prize. Hence the label 'the New Zealand Wars'.

However, labelling events of history, especially the history of warfare, is seldom easy and is rarely uncontested. ${ }^{5}$ Prior to "the New Zealand Wars' entering common usage, other names were attached to wars fought in New Zealand from 1843 to at least 1881. Until comparatively recently, the preferred term was 'the Maori Wars', a name that still persists in some quarters despite its divisive implications. It reflected the practice of the British Army in naming colonial wars after the enemy - hence the Zulu 
Wars, the Boer War, and the Maori Wars. ${ }^{6}$ Keith Sinclair underlined this term in 1957 when he examined the causes of the conflicts. ${ }^{7}$ However, he was to later concede that 'the Anglo-Maori Wars' was probably a better designation. 'The Anglo-Maori Wars' held popularity for a time, having been used first by Alan Ward in a 1967 essay reassessing the causes of the fighting. ${ }^{8}$ In that essay, Ward argued that ultimately the wars amounted to a series of sharp conflicts between two peoples, new Pakeha settlers and Maori. The conflicts of the 1860s came about because, after twenty years of fear and mistrust, a small and anxious white community (typical of other colonial situations, in Ward's view) wanted to force the issue - which people were to govern, and which people were to exist under the former's sufferance? A seemingly aloof and belligerent King Movement provided the perfect opportunity for the settlers to press the matter. The prospect of war in 1863 produced war fever on the streets of Auckland. Ward argued that the wars constituted a vast and defining conflict between the two peoples of this country - they were thus Anglo-Maori Wars. Somewhat paradoxically, despite Sinclair's eventual acceptance of this term, he was to argue in his final major work that the primary cause of war was still land, as he had argued in $1957 .{ }^{9}$

From about the mid-1970s, the term 'the Land Wars' won some acceptance, the issue of land being widely held to have been a critical underlying cause of the wars, especially in Taranaki and the Waikato. In 1986, for example, the Historic Places Trust indicated its clear preference for this term. According to a statement from the Trust, what to call the wars fought in New Zealand in the nineteenth century had become 'a problem to many New Zealand historians since the term "the Maori Wars" fell into disfavour'. Conceding that there was some debate on the issue, the Trust, on the advice of its Maori Advisory Committee, advised branches to use 'the Land Wars' in Trust publications. Branches were nevertheless to consult first with local Maori as to appropriate local Maori naming of these conflicts. Where a general term was needed, however, 'the Land Wars' was to be preferred over 'the New Zealand Wars'. ${ }^{10}$ As names go, however, it is fair to observe that the identifier 'the Land Wars' was never really popular, certainly not after James Belich popularised 'the New Zealand Wars'.

Yet, in literary terms at least, use of 'the New Zealand Wars' was hardly new. The label had been widely employed from the early 1920s, after publication of James Cowan's masterly two-volume history of the wars under that title. Cowan had spoken with many veterans of the later Armed Constabulary campaigns, and he had walked across most of the sites whilst they still bore evidence of battle. ${ }^{11}$ But Cowan and Belich used the name for different reasons. Cowan used the term to represent a series 
of wars fought between settlers and Maori somewhere out on the fringes of empire. These were wars fought to consolidate New Zealand's place within the British Empire. Belich took a very different stance. Consistent with most historians in the 1980s, Belich argued that the wars were largely an internal civil conflict fought over the sole right to govern. They were wars substantially removed from the context of empire. ${ }^{12}$ Belich also flatly rejected the term 'the Land Wars', considering it implied monocausality. It was a name which overly simplified the issue of causes. 'The Land Wars' suggested that the wars were all about the seizing of Maori land, and very little else, a view with which Belich did not agree.

Other names have also been advanced in recent years. For instance 'the Colonial New Zealand Wars' was the title suggested by Tim Ryan and Bill Parham in their illustrated 1986 book of the same name. ${ }^{13}$ The term 'New Zealand Civil Wars' has also been suggested from time to time, though it has not been argued with great conviction by any major New Zealand historian. Yet, ironically, there is much to suggest that the conflicts did in fact constitute a genuine New Zealand Civil War, a war between two distinct political groups (Crown and Maori), Maori being represented in later years by the King Movement. The difficulty with the concept of 'Civil War' in New Zealand seems to lie in a general perception that Maori did not constitute a single polity. There is a similar problem in the United States, there being a general reluctance to deem the wars against Indian tribes, especially the defining post 1860 Plains Wars, as American Civil Wars. Some historians have recently suggested that the nineteenth century New Zealand conflicts were in fact civil wars fought between groups of Maori, with settlers and the Crown almost relegated to the role of mere bystanders. ${ }^{14}$ It is certainly true that the later 1860s were characterised by significant kupapa ('friendly') Maori involvement, fighting against 'rebel' Maori, but the Crown interest was always at the core of the otherwise significant involvement of kupapa Maori. In truth, the British Army used few Maori to wage their campaigns. And, it was the British Army that 'won' the wars for the Crown, without the help of Maori. It is therefore disingenuous to suggest that 'the New Zealand Wars' were really civil wars fought between Maori tribes.

It is not unreasonable, then, to conclude that 'the New Zealand Wars' is the most widely accepted and used term. It has been picked up by historians as diverse as Chris Pugsley, Neil Finlay, Jock Phillips and Peter Maxwell. ${ }^{15}$ In fact, most historians who use it do not appear to do so for any particular reason. It tends to be used with the meanings attached to it by Belich accepted as a given. Either that, or the name is used uncritically. It has now taken on a life of its own, largely drained of substantive meaning. 'The New Zealand Wars' just sits out there as the accepted name. This naturally 
leads on to another question: does it really matter what we call these wars? What's in a name?

The answer, of course, is a great deal. The names we give to historical events are important because they speak volumes as to what we think about - in this case at least - such important issues as causes, who was involved, where precisely the events occurred, and who was responsible. There was percipience in the Historic Places Trust's 1986 suggestion that their branches should consult with local Maori before deciding on the name to use. A major issue hitherto largely overlooked by historians has been - what did Maori people think? It is plain that Maori people do have names for these wars. If it is possible to investigate how these names are derived, then perhaps it is equally possible to glean insights into how Maori participants and their descendants viewed issues like causes, places and extent of conflict, who was involved, and who was responsible.

In north Taranaki, the term 'Nga Pakanga Whenua O Mua' is one of the terms used amongst older Maori people to describe the years of conflict and war that frequently ravaged Maori settlements scattered from present day New Plymouth to Mokau in the north. 'Nga Pakanga' refers to the conflicts, or the wars; 'Whenua' refers to the land on which the wars were fought; 'O Mua' essentially means 'in years gone by.' So, in a sense, the term means 'The Land Wars.' 'The Land Wars' is the term most preferred by Maori, simply because the land was always the most important issue for Maori. Land was the reason why Maori were fighting. Wars fought over the land in fact predated the arrival of the British Army by centuries. When the nineteenth century wars were fought against the Crown the issues may have been different, perhaps more complex, but for Maori the concern was always the same - the land. Land represented everything to Maori: identity, sovereignty and history. To Maori, such wars were always 'the Land Wars'. To illustrate how this was so, it is proposed to look briefly at how warfare and land were intimately connected in Taranaki.

Throughout Taranaki there were at any time numerous hapu or sub tribes well established in distinct localities. Conflict and warfare were very much a part of their ordinary lives. Therefore, as specific conflicts arose, over time, specific area or hapu names tended to be attached to 'Nga Pakanga', each denoting a conflict involving a particular hapu, seen from their perspective as a part of long histories of conflict and warfare. So, for example, 'Nga Pakanaga Whenua O Mua Ki Manukorihi' denotes a conflict involving the Manukorihi people, the hapu from which Wiremu Kingi Rangitake came. Wiremu Kingi was the paramount chief of Te Atiawa who refused to permit the sale of the Waitara Block to the Crown in 1859; the chief around whom the tribes and hapu of north Taranaki formed an uneasy alliance when warfare against the Crown broke out at Te Kohia in 
1860. The Crown had earlier attempted to usurp the customary authority of Wiremu Kingi by over-ruling his authority to veto land sales. With the land sold, Kingi's refusal to permit the surveying of the disputed block precipitated the outbreak of war. Such a name as this, therefore, suggests a view of these events and past conflicts that impacted most on Manukorihi lands and people.

Such naming by Maori suggests two things. Firstly, the wars of the past were largely seen as a series of discrete if continuing engagements, only latterly involving new settlers and the Crown. This view accords with the convention within Maori history that hapu, mana and tradition reside at the centre of the Maori world view, and view of the past. Secondly, it indicates that for Maori the issue was the land, given that land represented all things to Maori, including the validity of descent, traditions, history, independence, tino rangatiratanga and identity. For Maori, 'sovereignty' without a clear connection to land was a tenuous notion. If the land was lost, so were all other things. For Maori, the issue in the final analysis was land.

In Taranaki, accounts of conflict and warfare, visited from beyond or fought out amongst the local tribes, always loomed large whenever tribal and hapu histories were recounted. There were accounts of battles, people, alliances and marriages that took place a long time ago. They were captured within whakapapa. In whakapapa, generations of people signified events, places and histories which together comprised the sum total of a tribe's history of mana. Such remembered forbears also comprised the history of a tribe's mana on the land. Whakapapa was the device that anchored Maori into these ancient landscapes.

From about the 1800s, this all came under fierce and sustained attack. Nga Puhi and Ngati Toa increasingly launched raids into Taranaki from the north. They were soon followed by the fearsome Waikato tribes, who as late as 1835 were still raiding south, deep into Taranaki. These incursions wreaked havoc throughout the Taranaki tribal domain, bearing heavily on the landscape and the people. Yet, while the impacts were grave, they did not effectively influence the essential Taranaki Maori apparatus of cognitive thinking and activity. The repercussions of Waikato on Taranaki were most severe. Ferocious battles would end with the complete destruction of villages, people and property, as occurred at Pukerangiora in 1830. Warring parties took few prisoners. Survivors usually fled to widely dispersed settlements. As Hugh Kawharu has pointed out, even when a disintegrated sub-tribe re-formed and regained its strength, it invariably chose a new settlement site. They did this because the 'blood of kinsmen (had been) spilled on the battleground', thus rendering old settlements tapu, or sacred. ${ }^{16}$

Immediately prior to European settlement in Taranaki, most parts of New Zealand were witness to the depredations of large and aggressive warring 
taua, emboldened by new strategies and devices of war, not the least of them the much-feared musket. Exacting destruction on real or imagined enemies of the past through conquest seems to have been the primary motivation for the conducting of these arduous and ferocious campaigns, often fought for negligible reward. The actual occupying of new land did not necessarily feature as a motive for the waging of war. But destroying the mana whenua of enemies did feature strongly as motivation. This would appear to have been the case, for example, with the later Ngati Toa raids into the South Island. Launched by Te Rauparaha, these invasions of terrible fury ranged as far south as Akaroa.

Such was also the case with the Waikato raids into Taranaki. Waikato did not remain in the area, occupying its conquered lands, long enough to constitute new title, though the conquerors believed they had extinguished the Taranaki whanui mana on the land. However, Taranaki Maori always saw matters differently. The missionary Octavius Hadfield was reported in 1860 as declaring that Waikato had not held possession of Waitara. As a consequence, Waikato had not acquired traditional rights to the district. On the other hand, the Waikato paramount chief Te Wherowhero, later first Maori King Potatau, threatened to dislodge the new European settlers from New Plymouth after 1841 because, he said, 'they did not buy the land from them who claim it in right of conquest'. In reality, he was claiming recognition of and compensation for the relinquishing of a now-fading Waikato political right over Taranaki. Given the variety of interests in land claimed by Maori at the time, Te Wherowhero was not necessarily denying local tribes their specific interests. Both sides would have known that the spiritual fires on the land established through the mana of Taranaki whakapapa could not be so easily extinguished. It might be conjectured further that the mana of Taranaki on the land could be translated as a legal order, common to all Maori, in fact outlawing conquest as a source of title. In other words, conquest did not extinguish long-standing customary title. Whatever, King Potatau of Waikato insisted that 'the remnants of the Ngatiawas are slaves; that they only live at Taranaki by my sufferance'. He was later prevailed upon, however, to accept 'compensation to the value of 250 pounds in return for the claims of his tribe on the lands of Taranaki'. ${ }^{17}$

To some extent, much of the history of the Taranaki tribes, hapu and communities after 1835 is an accounting of the tribes seeking to reimpose their mana whenua, and their mana histories, upon the landscape where 'the blood of kinsmen' lay in profusion. To them, the land remained the critical issue, that to which all other matters were attached. Such a process of reimposition was necessary as tribes sought to re-establish their mana whenua on the ancestral lands upon which their certainties of descent and identity were manifest. The advent of colonisation rendered this process of 
reimposition increasingly complex. Many claims were later made for land, reclaiming and cross-claiming occurring as tribes sought to define and impose their authority over lands once believed to have represented the continuum of their ancestry. Colonisation introduced many new issues to the process, especially that of land sales, which rendered more complex the assertions of tribes. Sales like those transacted by the Ngamotu Deed in New Plymouth were seriously flawed, and later attempts by Land Commissioner William Spain to remedy conflict between the New Zealand Company and local tribes appeased neither party. Maori people objected especially to a perceived ignorance of the customary imperatives of tribal land tenure. In the end, Spain rejected the legitimate claims presented by Te Atiawa. He could not comprehend, much less accept, the long-established and recognised customary system of land tenure.

Throughout the nineteenth century Maori people in Taranaki preserved whakapapa as their primary means of demonstrating lines of descent from important ancestors through 'complex lateral relationships'. Whakapapa remained a key device of 'intellectual management' with increased utility where appropriate as vehicle of a tribe's history. ${ }^{18}$ Whakapapa was always closely connected to land. After 1841 tribes, hapu and communities continued to construct and reconstitute their mana on the land to reflect the new realities out of the collective narratives of the past. Such histories and traditions of mana, and of holding the land, became the important collective focus for tribes and hapu, especially as they increasingly faced the processes of Crown enquiry. This was particularly so after 1860, processes of enquiry like the Native Land Court and the Compensation Court being all about defining complex land interests such as these, or at least establishing a basis for compensation for loss by recording such details from Maori.

The wars of 1860-61 were fought by the British Army in Taranaki against Taranaki Maori who were still resettling their customary lands. Later inquiries into the wars conclusively showed this to be the case. The situation was a tribal people defending ancient estates over which their precise hold was at times tenuous, especially given the recent histories of Waikato attrition, of migration, return and attempted reimposition of tenure based on whakapapa. Accordingly, whether to fight or not to fight against the British was often a difficult question for Maori to resolve. Some of the battles, like Puketekauere, were distinguished by large alliances of local Maori taking the field, with elements of Waikato in support. For other battles, like Mahoetahi, mounting a strong defence from within Te Atiawa proved difficult. Later investigations sought to distinguish between Maori who had 'adhered to the Queen' by not participating in the 'insurrection', as distinct from those who had participated but were repentant of having 
done so, those said to have 'rebelled but who shall submit to the Queen's authority. ${ }^{19}$

After 1863, 'rebels' - those who had borne arms against the Crown - were deemed to have forfeited their land. In reality, claimants were so numerous as to render such distinctions difficult to achieve prior to the convening of Compensation Court hearings. At that point, considerable effort was devoted to identifying rebel individuals, identifying those hapu members who were thought to have joined the fighting, or to have committed some act which brought them within the fifth clause of the New Zealand Settlements Act of 1863. Compensation Court Judge F.D. Fenton noted that 'for brevity's sake, I hereafter call this class of persons "rebels". ${ }^{20}$ Thereafter, separating 'loyalist' from 'rebel' was never straightforward. At any time during the hostilities, individuals or disparate groups of Maori throughout north Taranaki were likely as hapu and even tribes to have been involved, or not involved, in conflict with or in support of the Crown, or in conflict against each other. The term 'kupapa' therefore has limited value in Taranaki. It first referred to those Maori who were not involved in conflict, those who 'remained seated on the ground when others rose to the debate or departed for war'. ${ }^{21}$ Such neutrals were later described by colonists as friendly to the Crown, somewhat subverting the original meaning. It was later found to be generally not practicable to ascribe such status to specific hapu or tribes. This was because of the somewhat episodic nature of Maori involvement in the extended hostilities, but also reflecting the relative fluidity of the basic functional unit of Maori society in Taranaki at this time. Some tribes argued that they had remained loyal, while others had specifically demonstrated loyalty.

Substantiating loyalty to the Crown remained an important factor bearing on Maori prospects of successfully prosecuting retrospective claims for lost lands, claims which were as likely to be initiated by individuals or disparate groups of Maori as by hapu or tribes. In 1877, for example, Ruhia Teira sought the return of a portion of the southern Oakura Block. Following the lodgement of his petition, Teira was cross-examined on the question of loyalty: 'I will ask you whether your hapu generally was in rebellion'. Teira responded: 'about an equal number fought against the Government to those who supported them'. 'Were the principal men of the hapu under arms against the Government', Teira was asked. He replied, 'some of the principal men who remained quiet have died since the fighting. Some of them fought against the natives. ${ }^{22}$ Hemi Matenga's right to petition in 1878 for the return of Waitara South lands was similarly examined. To the question, 'were any members of (your) tribe in rebellion against her Majesty', Matenga replied, 'No, none of the Ngatihinetutu. The only one of them who remained behind was killed by the hau haus.' Later, 'was any portion of this tribe of which 
this hapu formed a part engaged in rebellion against the Queen?' Matenga replied, 'Some of the Ngati Awa were'. Then, in response to a further query as to numbers: 'I cannot say: I was in the north at the time'. ${ }^{23}$

Such testimony tells us many things about how individual Taranaki Maori families were affected by the wars of the 1860 s, and by the confiscations that followed. Of all issues that then weighed heavily upon Maori, none was as important as the fate of the land. This is why Maori viewed the wars of the 1860s through the context of land. There was really no other issue. This is why Maori have viewed the wars as 'Nga Pakanga Whenua O Mua - the Land Wars'.

1 James Belich, The New Zealand Wars and the Victorian Interpretation of Racial Conflict, Auckland, 1986.

2 Belich, op. cit., p.15.

3 For a description of the Te Kohia Pa engagement, see Belich, op. cit., pp.82-84.

4 Belich, op. cit., pp.291-310.

5 Wars invariably attract debate as to their proper naming, and causes. A good example is S.H. Steinberg, The 'Thirty Years War' and the Conflict for European Hegemony 1600-1660, London, 1966.

6 Keith Sinclair, Kinds of Peace. Maori People After the Wars 1870-1885, Auckland, 1991, pp.14-15.

7 Keith Sinclair, The Origins of the Maori Wars, Auckland, 1957.

8 Alan Ward, 'The Origins of the Anglo-Maori Wars. A Reconsideration', New Zealand Journal of History, vol. 1, no. 2, 1967, pp.148-70.

9 Sinclair, Kinds of Peace, Auckland, 1991, p.15.

10 Historic Places in New Zealand, December, 1986, p.32.

11 James Cowan, The New Zealand Wars and the Pioneering Period, Wellington, 1922.

12 Belich, op. cit., p.16.

13 Tim Ryan and Bill Parham, The Colonial New Zealand Wars, Auckland, 1986.

14 Peter Maxwell, Frontier. The Battle for the North Island of New Zealand, Auckland, 2000, pp.7-11.

15 Chris Pugsley, New Zealand Defence Quarterly, Autumn 1997, pp.32-36; Neil Finlay, Sacred Soil. Images and Stories of the New Zealand Wars, Auckland, 1998; Jock Phillips and Chris MacLean, The Sorrow and the Pride. New Zealand War Memorials, Wellington, 1990; Peter Maxwell, Frontier. The Battle for the North Island of New Zealand, Auckland, 2000.

16 Hugh Kawharu, Maori Land Tenure, Auckland, 1977, p.47.

17 Despatch from Governor Hobson to the Secretary of State, 13 November 1841; AJHR, 1860, E-No.2, p.5.

18 Tipene O'Regan, 'Old Myths and New Politics', New Zealand Journal of History, vol. 26, no. 1, 1992, p.25.

19 Report on Confiscated Lands, AJHR, 1873, C-4B, p.1.

20 Papers Relating to the Sitting of Compensation Court at New Plymouth, AJHR, 1866, A-No.13, p.3.

21 Eddie Durie, personal communication, 7 May 1994.

22 Petition No. 283/1876 (1876), Le 1/1877/5, National Archives, Wellington.

23 Petition No. 284/1878 (1878), Le 1/1878/6, National Archives, Wellington. 